\title{
ANALISIS YURIDIS TINDAKAN INVASIF OLEH PERAWAT PADA PRAKTIK KEPERAWATAN MANDIRI
}

\author{
Aris Prio Agus Santoso ${ }^{1}$, Musta'in ${ }^{2}$, Endrat Kartiko Utomo ${ }^{3}$, Aknes Galih Sumirat ${ }^{4}$ \\ ${ }^{1,4}$ Fakultas Hukum dan Bisnis, Universitas Duta Bangsa Surakarta \\ arisprio_santoso@udb.ac.id, Aknesgalig4@gmail.com \\ ${ }^{2,3}$ Fakultas Ilmu Kesehatan, Univesritas Duta Bangsa Surakarta \\ mustain@udb.ac.id, endrat_kartikon@udb.ac.id
}

\begin{abstract}
ABSTACT
Article 1 Permenkes No. 290/Menkes/Per/III/2008 states that an invasive procedure is a medical action that is recognized as the authority of a doctor. Facts in the field there are still nurses who carry out invasive actions without supervision from a doctor, even though the authority to carry out medical actions is only obtained if there is a delegation of authority from a doctor. This is where there is an overlap regarding the duties and authority of nurses who carry out invasive actions in independent nursing practice. The formulation of the problem in this study is to determine the authority and legal protection for nurses who perform invasive actions in independent practice.This research method uses a normative-sociological juridical approach with primary and secondary data collection. Primary data was obtained from literature review and also legislation or statutes of approach, and secondary data was obtained by purposive sampling technique. The type of design in this research is descriptive design. The data obtained were then analyzed qualitatively.The results show that nurses who already have a professional diploma, a Nurse Practice License and also a competency certificate have the authority to take invasive actions. The authority that is born is an overmacht state, giving rise to the attributive authority of the law of engagement. Such powers are permitted as long as they are exercised in accordance with the Standards. Legal protection is given to nurses on a preventive basis, namely by providing guidance and supervision by the health department and also the professional organization of the Indonesian National Nurses Association, although there is no Regional Regulation that regulates this action.
\end{abstract}

Keywords: Invasive Action, Nurse, Independent Practice.

\begin{abstract}
ABSTRAK
Pasal 1 Permenkes No. 290/Menkes/Per/III/2008 menyebutkan bahwa tindakan invasif adalah suatu tindakan medis yang diakui sebagai kewenangan dari dokter. Fakta di lapangan masih terdapat perawat yang melakukan tindakan invasif tanpa adanya pengawasan dari dokter, padahal kewenangan melaksanakan tindakan medis hanya diperoleh apabila ada pelimpahan wewenang dari dokter. Di sinilah terjadi terjadinya tumpang tindih mengenai tugas dan wewenang perawat yang melakukan tindakan invasif pada praktik keperawatan mandiri. Perumusan masalah dalam penelitian ini adalah mengetahui kewenangan dan perlindungan hukum bagi perawat yang melakukan tindakan invasif pada praktik mandiri. Metode penelitian ini menggunakan pendekatan yuridis normatif-sosiologis dengan pengumpulan data primer dan sekunder. Data primer diperoleh dari kajian kepustakaan dan juga perundang-undangan atau statuta aproach, dan data sekunder diperoleh dengan teknik purposive sampling. Tipe desain dalam penelitian ini adalah Descriptive Design. Data yang diperoleh selanjutnya dianalisis secara kualitatif. Hasil penelitian menunjukan bahwa perawat yang telah memiliki ijazah profesi, SIPP dan juga sertifikat kompetensi memiliki kewenangan melakukan tindakan invasif. Kewenangan yang lahir merupakan keadaan overmacht sehingga menimbulkan kewenangan atributif dari hukum perikatan. Kewenangan tersebut diperbolehkan selama dilakukan sesuai dengan Standar. Perlindungan hukum diberikan kepada perawat secara preventif yakni dengan melakukan pembinaan dan pengawasan oleh dinas kesehatan dan juga organisasi profesi PPNI meskipun belum ada Peraturan Daerah yang mengatur tentang tindakan tersebut.
\end{abstract}

Kata Kunci: Tindakan Invasif, Perawat, Praktik Mandiri. 


\section{PENDAHULUAN}

Pembangunan kesehatan adalah salah satu unsur kesejahteraan umum yang wajib diwujudkan oleh pemerintah sesuai dengan nawa cita bangsa Indonesia sebagaimana di maksud dalam UUD (1945), yaitu membentengi segenap bangsa Indonesia dan seluruh tumpah darah Indonesia serta untuk meningkatkan kesejahteraan umum, mencerdaskan kehidupan bangsa dan ikut melaksanakan ketertiban dunia berdasarkan kemerdekaan, perdamaian abadi dan keadilan sosial.

Kesehatan adalah hak asasi manusia dan merupakan unsur kesejahteraan yang wajib diwujudkan negara sesuai dengan cita-cita bangsa Indonesia. Oleh sebab itu, setiap kegiatan harus dilaksanakan sesuai dengan prinsip non diskriminatif, partisipatif, perlindungan, dan berkelanjutan yang sangat penting artinya bagi peningkatan ketahanan dan daya saing bangsa, pembentukan sumber daya manusia Indonesia, dan pembangunan nasional dalam upaya untuk meningkatkan derajat kesehatan masyarakat yang setinggitingginya.

Salah satu usaha yang dilaksanakan untuk meningkatkan derajat kesehatan adalah melalui praktik mandiri, baik dilakukan oleh dokter, bidan, perawat, maupun tenaga kesehatan lainya untuk mengurangi peningkatan dan penularan penyakit di masyarakat, khususnya di daerah pedesaan. Perawat sebagai salah satu tenaga kesehatan yang melaksanakan pelayanan kesehatan kepada masyarakat umum. Tugas utama perawat yaitu melakukan asuhan keperawatan atau memberikan pelayanan kesehatan yang sesuai dengan skill dan keahlian yang dimilikinya. Perawat dalam memberikan pelayanan keperawatan terdapat beberapa peran. Pertama, perawat memiliki peran dalam mengatasi masalah yang dihadapi pasien. Kedua, perawat memiliki tanggung jawab dalam memberikan penyuluhan kepada klien/pasien. Ketiga, perawat memiliki peran dalam memantau dan menjamin kualitas asuhan keperawatan. Keempat, perawat memiliki tugas sebagai peneliti dalam upaya untuk mengembangkan body of knowledge keperawatan. Karena keahlianya yang diperoleh dari pengalaman, sehingga tidak jarang ditemukan di beberapa lokasi, seorang perawat melakukan tindakan medis layaknya seorang dokter. Tindakan medis seharusnya dilakukan oleh dokter, kini juga dilakukan oleh perawat dalam praktik keperawatan mandirinya. Tindakan medis yang dilakukan oleh dokter memiliki tujuan untuk kesembuhan pasien yang dilakukan dengan cara tindakan operasi ataupun pengobatan, sedangkan tindakan keperawatan memiliki tujuan untuk mempertahankan atau meningkatkan kesehatan optimal pasien. Perawat dalam melaksanakan tugasnya haruslah selalu di bawah pengawasan dokter, sebab dalam praktik keperawatan terdapat fungsi depedent, yang mana dalam fungsi ini perawat bertindak membantu dokter dalam memberikan pelayanan medis. Perawat membantu dokter memberikan pelayanan dalam hal pengobatan dan tindakan khusus yang menjadi wewenang dokter dan seharusnya dilakukan oleh dokter, seperti pemasangan infus, melakukan suntikan, dan pemberian obat-obatan.

Fakta di lapangan banyak perawat melakukan tindakan medis atau tindakan invasif tanpa adanya pengawasan dari dokter, padahal kewenangan perawat adalah kewenangan dalam melakukan tindakan asuhan keperawatan, sedangkan kewenangan melaksanakan tindakan medis hanya didapatkan apabila ada pelimpahan wewenang dari dokter.

Seperti yang dikutip dari berita Radar Bojonegoro tanggal 27 Mei 2018, bahwa Ikatan Dokter Indonesia (IDI) menolak Raperda Perizinan Praktik Mandiri Perawat karena dinilai bertentangan dengan regualasi di atasnya, selain itu rawan terjadi malpraktik di lapangan yang dikhawatirkan akan memakan korban. Seperti dikutip juga dari berita News.okezone.com tanggal 10 September 2018, seorang perawat pensiunan PNS Puskesmas Doro ditangkap Polisi karena tanpa sengaja memotong ujung alat kelamin (glans penis) pasien bocah yang sedang menjalani proses khitan di Kabupaten Pekalongan, Jawa Tengah. 
Data dari Persatuan Perawat Nasional Indonesia mengenai malpraktik keperawatan di Indonesia pada tahun 2010-2015 ada sekitar 485 kasus. Dari 485 kasus malpraktik tersebut, 46 kasus terjadi akibat tindakan medik tanpa persetujuan dari dokter yang dilakukan dengan tidak hati-hati dan menyebabkan luka serta kecacatan kepada pasien atau tergolong dalam malpraktik kriminal dengan unsur kelalaian, 82 kasus perawat yang tidak memberikan prestasinya sebagaimana yang disepakati dan termasuk dalam malpraktik sispil, dan 357 kasus malpraktik administrative.

Pasal 1 Permenkes No. 290/Menkes/Per/III/2008 menyebutkan bahwa tindakan Invasif adalah suatu tindakan medis yang langsung dapat mempengaruhi keutuhan jaringan tubuh pasien. Sangat dimungkinkan bahwa tindakan invasif, seperti; injeksi, sirkumsisi, dan lain sebagaianya yang dilakukan oleh perawat merupakan tindakan medis dan merupakan kewenangan dari dokter. Di sinilah terjadi dilema hukum di bidang kesehatan, ditambah belum tersedia dan adanya petunjuk atau peraturan mengenai jenis-jenis tindakan medis yang dapat dilakukan oleh perawat seringkali menyebabkan terjadinya tumpang tindih tentang tugas asuhan keperawatan dan tugas yang merupakan pelimpahan dari kewenangan dokter.

\section{METODE PENELITIAN}

Metode penelitian ini menggunakan pendekatan yuridis normatif dan yuridis sosiologis dengan tipe desain penelitian yang digunakan adalah Descriptive Design. Teknik pengumpulan data dalam penelitian ini dilakukan dengan cara pengumpulan data dari data primer dan sekunder. Data primer diperoleh dari kajian kepustakaan dan juga perundang-undangan atau statuta aproach, sedangkan data sekunder diperoleh dengan teknik purposive sampling terhadap perawat yang melakukan Tindakan invasif pada praktik keperawatan mandiri melalui kuesioner. Jumlah sampel dalam penelitian ini sebanyak 7 responden di seluruh Kota Surakarta. Teknik analisis data dalam penelitian ini menggunakan teknik analisis kulitatif, untuk menjawab permasalahan tentang kewenangan perawat dalam melakukan tindakan invasif dan perlindungan hukum perawat yang melakukan tindakan invasif pada praktik keperawatan mandiri.

\section{HASIL DAN PEMBAHASAN}

Data yang diperoleh dari Informasi SDM Kesehatan Badan PPSDM Kementerian Kesehatan RI Per tanggal 31 Desember 2020, menunjukkan jumlah perawat di Provinsi Jawa Tengah sebanyak 5370 Jiwa. Di Surakarta sendiri jumlah perawat sebanyak 853 Jiwa Per tanggal 31 Desember 2020. Sedangkan data perawat yang melakukan Praktik Keperawatan Mandiri berjumlah 7 orang saja dalam data yang dimiliki oleh Dinkes Kota Surakarta terkait dengan proses perizinan praktik mandiri yang dikeluarkan. Data yang diperoleh ini diperkuat dengan pernyataan Yuli Muhammad Kartiko yang mengatakan bahwa perawat yang ada di Kota Surakarta ini, paling banyak melakukan praktik mandiri di luar daerah Kota Surakarta, seperti di Karanganyar, Boyolali, Sragen, dan Sukoharjo, sehingga untuk data pastinya dari DPD PPNI Kota Surakarta sendiri belum mengetahuinya.

\section{a. Kewenangan Perawat dalam melakukan Tindakan Invasif pada Praktik Keperawatan Mandiri \\ 1) Ditinjau dari Filsafat Hukum}

a) Ontologi

Ontologi merupakan sesuatu yang telah ada, baik secara jasmani dan rohani. Ontologi bisa dirumuskan sebagai ilmu yang mempelajari realitas atau kenyataan konkret yang kritis. Kenyataan di masyarakat bahwa masyarakat lebih sering berobat di tempat praktik keperawatan mandiri. Jika ada persepsi dari masyarakat awam yang sering mengatakan bahwa perawat itu adalah dokter, itu tidak bisa disalahkan karena hal ini merupakan realitas atau kenyataan konkret yang tumbuh dipikiran masyarakat. Tinggal bagaimana perawat tersebut menjelaskan tentang profesinya saat melakukan tindakan kepada pasien yang 
sedang ditanganinya. Jika ada oknum yang ingin menjebloskan perawat ke sel tahanan karena telah melakukan tindakan medis dan/atau berpura-pura sebagai dokter, sebagaimana Pasal 78 UU No. 29/2004 tentang Praktik Kedokteran, maka tindakan ini merupakan kesalahan besar, karena letak akar masalahnya bukan pada perawat tersebut melainkan ada pada persepsi masyarakat yang telah tumbuh dan berkembang sejak lama. Perawat tidak dapat dipersalahkan jika melakukan tindakan invasif mengingat bahwa kenyataan membuktikan bahwa perawat tersebut memiliki kompetensi yang serupa dengan dokter, sedangkan apa yang terjadi bukanlah kemauan perawat tersebut melainkan realitas yang telah ada yang menuntut perawat untuk terus melakukanya demi memberikan pelayanan yang terbaik.

b) Epistemologi

Epistemologi merupakan aspek teori dan pengetahuan yang benar. Epistemologi berkaitan dengaan asal, sifat, metode dan batasan pengetahuan manusia. Oleh sebab itu epistemologi juga disebut teori pengetahuan. Pengetahuan dan ketrampilan akan hal tindakan invasif yang dilakukan oleh perawat diperoleh dari pendidikan dan juga pelatihan. Hal ini ditunjukkan dari hasil kuesioner yang dibagikan kepada responden, yakni;

Tabel: 1.1

Jenis Sertifikat Perawat

\begin{tabular}{lccc}
\hline \multicolumn{1}{c}{ Jenis } & Ada (\%) & $\begin{array}{c}\text { Tidak } \\
\text { Ada } \\
(\%)\end{array}$ \\
\hline $\begin{array}{l}\text { Kepemilikan } \\
\text { D3/S1 Keperawatan }\end{array}$ & $100 \%$ & - \\
$\begin{array}{l}\text { Kepemilikan } \\
\text { Kompetensi }\end{array}$ & $\begin{array}{r}\text { Sertifikat } \\
\text { (Rawat }\end{array}$ & $100 \%$ & - \\
$\begin{array}{l}\text { Luka, } \\
\text { Sirkumsisi) }\end{array}$ & Bekam, & & \\
\hline
\end{tabular}

Hasil tersebut di atas menunjukkan bahwa perawat sudahmemiliki ketrampilan di bidangnya, dibuktikan dengan ijazah dan sertifikat kompetensi yang dimilki. Seorang perawat mustahil akan melakukan tindakan-tindakan yang berisiko seperti tindakan invasif jika perawat tersebut tidak memiliki pengetahuan dan kompetensi di bidang tersebut.

c) Aksiologi

Aksiologi merupakan nilai-nilai sebagai tolak ukur kebenaran, etika dan moral. Jika bagian filsafat ini dikaitkan dengan hasil kuesioner yang dibagikan kepada perawat yang melakukan tindakan invasif pada praktik keperawatan mandiri, yakni:

Diagram: 1.1

Alasan Perawat Melakukan Tindakan Invasif

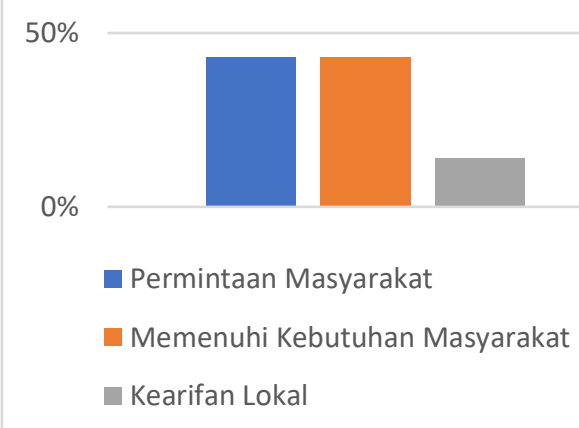

Maka dapat diartikan bahwa tindakan invasif tersebut merupakan bentuk nilai kemanusiaan yang dilakukan oleh perawat tersebut dengan mengedepankan etika profesi dan patient safety dalam setiap tindakanya. Hal ini dilakukan mengingat banyaknya permintaan masyarakat untuk memberikan pelayanan yang sesuai yang diinginkan.

Jika ketiga bagian filsafat di atas dikaitkan dengan konsep teori keadilan maka diperoleh bahwa situasi yang dialami oleh perawat yang melakukan tindakan invasif merupakan situasi terdesak dan situasi paksaaan yang bukan diperoleh dari kewenangan atribusi 
melainkan oleh masyarakat itu sendiri atas dasar itikad baik. Di sini keadilan hukum harus ditegakkan agar semua perawat memiliki peluang yang sama besar dalam hidup meskipun terbatas dengan kompetensi yang mereka miliki. Hal ini diperkuat dengan Teori John Rawls yang menyebutkan bahwa keadilan yang berdimensi kerakyatan haruslah memperhatikan 2 (dua) prinsip:

a) Memberi kesempatan dan hak yang sama atas kebebasan dasar yang paling luas seluas kebebasan yang sama bagi setiap orang.

b) Mengatur kembali kesenjangan sosial yang terjadi sehingga mampu memberikan keuntungan yang bersifat timbal balik bagi setiap orang, baik yang berasal dari kelompok tidak beruntung maupun kelompok yang beruntung.

Ketika seorang pasien datang berobat ketempat perawat, itu artinya bahwa pasien tersebut menjadi hak dan tanggungjawabnya. Orang lain tidak dapat melarangnya karena keadilan menjadi dasar bagi tiap hukum positif yang bermartabat sedangkan perikatan yang terjadi antara pasien dan perawat menjadi sumber hukum yang tercipta untuk mencapai tujuan bersama, menjaga ikatan sosial atau sebaliknya agar tidak melakukan bertindak yang dapat merusak tatanan keadilan.

2) Ditinjau dari Pendekatan Kebiasaan

Dalam kamus besar bahasa Indonesia Departemen Pendidikan dan Kebudayaan (DEPDIKBUD), menyebutkan kebiasaan merupakan sesuatu yang biasa dilakukan, kebiasaan berarti juga pola untuk melakukan tanggapan terhadap situasi tertentu yang dipelajari oleh seorang individu dan yang dilakukannya secara berulang untuk hal yang sama.
Lexy J. Moleong mengatakan bahwa kebiasaan adalah cara berbuat atau bertindak yang dimiliki seseorang dan diperolehnya melalui proses belajar cara tersebut bersifat seragam, tetap, dan otomatis. Kebiasaan merupakan perbuatan manusia yang tetap dikerjakan berulang-ulang dalam hal yang sama. Apabila suatu kebiasaan tertentu diterima oleh masyarakat dan kebiasaan itu selalu berulang-ulang dikerjakan sedemikan rupa, sehingga tindakan yang berlawanan dengan kebiasaan itu dirasakan sebagai pelanggaran perasaan hukum, maka dengan demikian timbullah suatu kebiasaan hukum, yang oleh pergaulan hidup dipandang sebagai hukum.

Kebiasaan merupakan semua peraturan yang meskipun tidak ditetapkan oleh pemerintah, tetapi ditaati oleh seluruh rakyat karena mereka yakin bahwa peraturan itu berlaku sebagai hukum. Agar kebiasaan itu mempunyai kekuatan dan dapat dijadikan sebagai sumber hukum, maka ditentukan oleh 2 (dua) faktor yaitu:

a) Adanya perbuatan yang dilakukan berulang kali dalam hal yang sama yang selalu diikuti dan diterima oleh orang yang lainnya.

b) Adanya keyakinan hukum dari orang-orang atau golongangolongan yang berkepentingan. Maksudnya adanya keyakinan bahwa kebiasaan itu memuat halhal yang baik dan pantas ditaati serta mempunyai kekuatan mengikat.

Di dalam masyarakat, kenyataan keberadaan kebiasaan diakui sebagai norma hukum yang patut dipatuhi. Dipatuhinya kebiasaan ini karena adanya kekosongan hukum tertulis yang sangat dibutuhkan oleh masyarakat/negara.

Dari kuesioner yang dibagikan kepada 7 (tujuh) perawat yang melakukan praktik mandiri diperoleh hasil: 
Tabel: 1.2

Jenis Tindakan Invasif yang Dilakukan Oleh Perawat

\begin{tabular}{|c|c|c|c|c|c|c|}
\hline $\begin{array}{c}\text { Tindakan } \\
\text { Invasif }\end{array}$ & Injeksi & $\begin{array}{c}\text { Sirkum } \\
\text { sisi }\end{array}$ & $\begin{array}{l}\text { Bek } \\
\text { am }\end{array}$ & $\begin{array}{c}\text { Aku } \\
\text { pun } \\
\text { tur }\end{array}$ & $\begin{array}{c}\text { Pem } \\
\text { asan } \\
\text { gan } \\
\text { Infu } \\
\text { s } \\
\end{array}$ & $\begin{array}{l}\text { Necro } \\
\text { tomy }\end{array}$ \\
\hline Perawat 1 & $\sqrt{ }$ & $\sqrt{ }$ & $\sqrt{ }$ & & $\sqrt{ }$ & $\sqrt{ }$ \\
\hline Perawat 2 & $\sqrt{ }$ & & & & & $\sqrt{ }$ \\
\hline Perawat 3 & $\sqrt{ }$ & $\sqrt{ }$ & & & $\sqrt{ }$ & $\sqrt{ }$ \\
\hline Perawat 4 & $\sqrt{ }$ & & & & & $\sqrt{ }$ \\
\hline Perawat 5 & $\sqrt{ }$ & $\sqrt{ }$ & & & $\sqrt{ }$ & $\sqrt{ }$ \\
\hline Perawat 6 & $\sqrt{ }$ & & & & & $\sqrt{ }$ \\
\hline Perawat 7 & $\sqrt{ }$ & & & & $\sqrt{ }$ & $\sqrt{ }$ \\
\hline
\end{tabular}

Data di atas menunjukkan bahwa tindakan invasif yang banyak dilakukan oleh perawat yang melakukan praktik keperawatan mandiri di Kota Surakarta kebanyakan injeksi dan juga necrotomy (perawatan luka).

Jika data di atas dihubungakan dengan pernyataan Thorndike yang mengatakan suatu teori yang disebut "laws of exercise and effect". Maka suatu kegiatan yang mampu dilakukan dengan baik dan sempurna bila kegiatan itu dilakukan secara terbiasa. Sehingga hal ini dapat memotivasi orang lain melakukan hal yang sama agar memperoleh hasil yang memuaskan. Kemudian, jika teori ini ditarik ulur dengan tindakan invasif dalam pelayanan keperawatan, maka sudah sewajarnya apabila perawat mengikuti jejak-jejak para pendahulunya karena dinilai kebiasaan tersebut dapat memberikan hasil yang memuaskan baik bagi klien maupun bagi dirinya sendiri. Namun demikian, justru kebiasaan ini dijadikan sumber permasalahan dalam hukum keperawatan terutama dari segi unsur kewenanganya.

Kebiasaan tindakan pengobatan yang turun temurun misalnya adalah bekam, dan sirkumsisi. Bekam telah dikenal sejak kerajaan Sumeria, kemudian terus berkembang sampai Babilonia, Saba, Mesir kuno, dan Persia. Pada zaman Nabi Muhammad, juga menggunakan tanduk sapi atau kerbau, gading gajah, tulang unta. Kemudian, kebiasaan sirkumsisi pertama kali dikenalkan pada zaman perdaban mesir kuno. Masyarakat mesir melakukan sirkumsisi di awal abad 23 sebelum masehi. Di Era Modern ini, tindakan bekam dan sirkumsisi sudah mulai dikembangkan dengan menggunakan alat-alat kedokteran yang memiliki prinsip safety. Akan tetapi hal ini mulai dijadikan perdebatan oleh berbagai pihak, dimana mereka saling merebutkan kewenangan terkait tindakan invasif jenis ini. Jika hal ini dikembalikan pada pendekatan filsafat hukum maka kebiasaan yang demikian itu akan menjadi sumber hukum murni yang memperbolehkan siapapun untuk dapat melakukan tindakan tersebut tidak peduli mereka dari kasta apa dan juga dari profesi apa karena semua pada prinsipnya sama, terlebih pengobatan ini merupakan tradisi yang harus tetap dijalankan apalagi di masa lampau tindakan ini bukan jadi perebutan, melainkan menjadi kebiasaan bagi siapapun yang memiliki kompetensi tersebut.

Jika ditinjau dari konsep kebiasan seperti yang telah diuraikan di atas, seorang perawat yang senantiasa merawat dan mengobati masyarakat menggunakan tindakan invasif di pedesaan maupun perkotaan sebagai bentuk keprofesionalitasan suatu profesi, maka segala sesuatu yang dilakukan perawat ini menjadi bagian dari kebudayaan suatu masyarakat/profesi itu sendiri yang terpenting perawat tersebut memiliki kompetensi dan memperhatikan prinsip safety.

Hal tersebut di atas sama dengan yang disampaikan Tampubulon yang mendefinisikan bahwa kebiasaan merupakan sikap atau kegiatan, baik mental maupun fisik, yang telah membudaya dalam suatu masyarakat. Ini menunjukkan bahwa setiap orang harus menghargai dan menghormati kebiasaan tersebut, dan ini juga akan menjadi bentuk keadilan dan keharmonisan hukum. 
Pasal 28D (1) UUD 1945 menyebutkan bahwa setiap orang berhak atas pengakuan, jaminan, perlindungan, dan kepastian hukum yang adil serta perlakuan yang sama dihadapan hukum. dan kepastian yang sama dihadapan hukum. Maka, kebiasaan yang dilakukan oleh perawat tersebut di atas paling tidak mendapatkan pengakuan dan jaminan sekalipun apa yang ia lakukan belum secara eksplisit di jabarkan dalam konsep hukum positif. Meskipun demikian, bahkan seorang hakim pun harus menghormati apa yang telah dilakukan perawat, karena apa yang dilakukan merupakan panggilan jiwa untuk menolong sesama manusia (memiliki itikad baik). Prinsip inilah yang harus dipertimbangkan jika terjadi kasus hukum perawat yang melakukan tindakan ivasif. Sebagaimana yang tertuang dalam Keputusan Bersama Ketua Mahkamah Agung RI dan Ketua Komisi Yudisial RI Nomor: 047/KMA/SKB/IV/2009, dan Nomor: 02/SKB/P.KY/IV/2009 Tentang Kode Etik Dan Pedoman Perilaku Hakim yang menyebutkan bahwa Hakim harus bijaksana dan arif artinya mampu bertindak sesuai dengan norma-norma yang hidup dalam masyarakat baik norma-norma keagamaan, norma-norma hukum, kebiasan-kebiasan maupun kesusilaan dengan memperhatikan situasi dan kondisi pada saat itu, serta mampu memperhitungkan akibat dari tindakannya. Maka dalam memutuskan perkara, hakim harus dapat memperhatikan norma kesusilaan yang berasal dalam hati nurani perawat yang dengan baik hati menolong dan menyelamatkan pasien yang sedang ditanganinya.

3) Ditinjau dari Hukum Administrasi Negara

Kewenangan adalah kekuasaan formal yang bersumber dari undangundang, sedangkan wewenang adalah suatu spesifikasi dari kewenangan, artinya barang siapa (subyek hukum) yang diberikan kewenangan oleh undang-undang, sehingga ia berwenang untuk melakukan sesuatu yang tersebut dalam kewenangan itu.

Dalam hukum publik, wewenang berkaitan dengan kekuasaan. Kekuasaan merupakan kemampuan secara umum untuk menjamin pelaksanaan dari kewajibankewajiban yang mengikatnya.

Ada sumber kekuasaan yang berkaitan dengan praktik keperawatan mandiri, yaitu:

a) Legitimate power : adalah kekuasaan yang diperoleh karena surat perintah, atau karena mendapat ijazah. Misalnya seorang perawat yang memiliki ijazah Pendidikan Perguruan Tinggi.

b) Expert Power : adalah kekuasaan yang diperoleh karena seseorang tersebut memiliki keahlian tertentu/ kompetensi. Misalnya seorang perawat memiliki keahlian sunat, bekam, perawatan luka, dan lain sebagainya yang dibuktikan dengan sertifikasi kompetensi.

c) Reverent Power : adalah kekuasaan yang diperoleh karena mempunyai daya tarik tertentu. Misalnya karena ramai dan murahnya biaya pengobatan di tempat praktik mandiri sehingga menimbulkan daya tarik tinggi di masyarakat.

Dari konsep di atas, jika ditarik ulur maka diperoleh rumus bahwa kewenangan merupakan kekuasaan yang diperoleh subjek hukum atas dasar kemampuan yang dimiliki untuk menjalankan suatu wewenang tersebut sedangkan kemampuan sendiri berkaitan erat dengan kompetensi.

Wibowo, menyebutkan bahwa kompetensi merupakan suatu kemampuan untuk melakukan atau melaksanakan suatu pekerjaan atau tugas yang dilandasi atas pengetahuan dan ketrampilan serta didukung oleh sikap kerja yang dituntut oleh pekerjaan tersebut. Dengan demikian, kompetensi menunjukkan pengetahuan atau ketrampilan yang dicirikan oleh profesionalisme dalam 
suatu bidang tertentu sebagai sesuatu yang terpenting, sebagai unggulan bidang tertentu, dengan indikatornya adalah; pengetahuan, ketrampilan dan sikap. Sedangkan Moh. Uzer Usman menyebutkan bahwa, seseorang bida dikatakan kompeten apabila telah memiliki kecakapan bekerja pada bidang tertentu dari hal ini maka kompetensi dapat diartikan juga sebagai suatu hal yang menggambarkan kualifikasi atau kemampuan seseorang, baik yang kuantitatif maupun kualitatif. Kompetensi diporeh dari:

a) Pendidikan Formal (Pendidikan dari Perguruan Tinggi)

b) Pendidikan Non Formal (Pelatihan, Warisan, dan Tradisi).

Dari kuesioner yang dibagikan kepada perawat yang melakukan tindakan invasif pada praktik keperawatan mandiri diperoleh hasil bahwa 7 perawat yang mendirikan praktik keperawatan mandiri tersebut telah memiliki ijazah Pendidikan formal dan sertifikat kompetensi yang diperoleh dari pelatihan.

\section{4) Ditinjau dari Peraturan} Perundang-Undangan

Pasal 28 Ayat (8) Permenkes No. 26/2019 tentang Peraturan Pelaksanaan UU No. 38/2014 Tentang Keperawatan, menyebutkan bahwa jenis tindakan medis dalam pelimpahan wewenang secara delegatif meliputi tindakan:

a) Memasang infus;

b) Menyuntik;

c) Imunisasi dasar; dan

d) Tindakan medis lainnya yang dilakukan sesuai dengan kompetensi.

Pasal 28 Ayat (9) menjelaskan bahwa, jenis tindakan medis lainnya dalam pelimpahan wewenang secara mandat atau delegatif ditetapkan oleh:

a) Pimpinan rumah sakit bagi pelimpahan wewenang yang dilakukan dari tenaga medis di rumah sakit atas usulan komite medik dan komite keperawatan; dan b) Kepala dinas kesehatan pemerintah daerah kabupaten/kota bagi pelimpahan wewenang yang dilakukan dari tenaga medis di pusat kesehatan masyarakat dan/atau klinik atas usul kepala pusat kesehatan masyarakat dan/atau pimpinan klinik.

Jika pasal tersebut dicermati lebih mendalam, maka akan diperoleh bahwa pasal tentang pelimpahan wewenang itu hanya berlaku di fasilitas pelayanan Kesehatan, seperti; rumah sakit, klinik, dan puskesmas. Pada pasal tersebut tidak menjelaskan tentang praktik keperawatan mandiri, sehingga di sini terjadilah kekosongan hukum di mana tidak ada peraturan pelimpahan wewenang oleh dokter di praktik keperawatan mandiri sedangkan fakta di lapangan telah terjadi permintaan pengobatan invasif dari masyarakat. Dalam hal ini perkembangan masyarakat yang lebih cepat dari pada perkembangan peraturan perundang-undangan menjadi masalah berkaitan dengan hal-hal yang belum atau tidak diatur dalam Peraturan PerundangUndangan, karena berdasarkan pernyataan tersebut bisa diambil suatu konklusi bahwa tidak mungkin suatu peraturan perundang-undangan dapat mengatur segala kehidupan manusia secara tuntas sehingga memungkinkan terjadinya keadaan dimana aturan yang ada di suatu Negara dianggap tidak lengkap dan tidak menjamin kepastian hukum warganya yang berakibat adanya kekosongan hukum (rechtsvacuum) di masyarakat. Sehingga kebiasaan di sini dapat dijadikan sumber hukum untuk mengisi kekosongan hukum tersebut. Sebagaimana yang dikatakan Soerjono Soekanto dan Mustafa Abdullah bahwa kaidah hukum berlaku secara sosiologis, apabila kaidah tersebut efektif, artinya kaidah tersebut berlaku karena di terima dan diakui oleh masyarakat karena masyarakat dalam hal ini menjadi satu faktor yang cukup memengaruhi di 
dalam efektivitasnya hukum. Jika tujuan hukum tercapai, yaitu bila perawat dan pasien berperilaku sesuai dengan yang diharapkan atau dikehendaki oleh hukum (saling melengkapi antara hak dan kewajiban), hal ini kan menjadi hukum efektif.

Gerardus Gegen menjelaskan, pada Pasal 32 Permenkes No. 26/2019 sebenarnya telah menyebutkan bahwa jika di daerah tempat perawat (praktik mandiri) melakukan tindakan invasif telah terdapat tenaga medis dan/atau tenaga kefarmasian, maka tidak berlaku kewenangan melakukan pengobatan untuk penyakit umum, merujuk Klien, dan melakukan pelayanan kefarmasian secara terbatas. Akan tetapi jika hal ini dikaitkan dengan Pasal 5 ayat (3) UU No. 36/2009 tentang Kesehatan yang berbunyi bahwa Setiap orang berhak secara mandiri dan bertanggung jawab menentukan sendiri pelayanan kesehatan yang diperlukan bagi dirinya, maka ini artinya memberikan kebebasan kepada pasien untuk memperoleh pelayanan kesehatan kepada siapapun yang dipercayainya. Pilihan pasien ini akan menjadi sebuah perikatan yang melahirkan hukum, dan hukum itu sah ketika dua belah pihak saling melaksanakan hak dan kewajibanya. Karena pada dasarnya yang dilakukan oleh perawat tersebut adalah sutu prestasi atas permintaan dari pasien itu sendiri, maka ini dapat dijadikan sumber hukum. Lagipula hal tersebut merupakan keadaan overmacht, di mana perawat melakukan tersebut atas dasar aspek kemanusiaan. Sehingga Pasal 36 huruf a UU No. 38/2014 dapat diberlakukan, di mana dalam Pasal tersebut perawat berhak memperoleh pelindungan hukum sepanjang melaksanakan tugas sesuai dengan standar pelayanan, standar profesi, standar prosedur operasional, dan ketentuan Peraturan Perundangundangan (perjanjian yang lahir antara klien dan perawat juga termasuk perundang-undangan meskipun tidak tertulis).

Jika perikatan tersebut di atas dikaitkan dengan Pasal 1320 KUHPerdata tentang syarat sahnya perjanjian yakni, adanya kesepakatan kedua belah pihak, kecakapan, adanya objek/perihal tertentu, dan causa yang halal (tidak bertentangan dengan peraturan perundang-undangan). Maka itu bukanlah sebuah pertentangan melawan hukum. Karena apa yang dilakukan perawat bukanlah causa yang tidak halal/ perbuatan yang haram atau yang ditentang oleh peraturan perundang-undangan. $\mathrm{Hal}$ ini diperkuat dengan Pasal 9 Ayat (1) dan (2) UU No. 36/2009 tentang Kesehatan bahwa Setiap orang berkewajiban ikut mewujudkan, mempertahankan, dan meningkatkan derajat kesehatan masyarakat yang setinggi-tingginya. Kewajiban tersebut pelaksanaannya meliputi upaya kesehatan perseorangan, upaya kesehatan masyarakat, dan pembangunan berwawasan kesehatan. Dilanjutkan Pasal 12 yang menyebutkan bahwa setiap orang berkewajiban menjaga dan meningkatkan derajat kesehatan bagi orang lain yang menjadi tanggung jawabnya.

Pasal 1 Permenkes No. 290/Menkes/Per/III/2008

menyebutkan, tindakan invasif adalah suatu tindakan medis yang langsung dapat mempengaruhi keutuhan jaringan tubuh pasien. Tindakan invasif menurut Noor M. Aziz adalah meliputi; injeksi, pemasangan infus, pemasangan kateter dan lain sebagainya. Dhony Firmansyah menyebutkan, alat kesehatan invasif adalah alat kesehatan yang menembus ke dalam tubuh secara keseluruhan atau sebagian, baik melalui lubang tubuh atau melalui permukaan tubuh. Menurut Kamus Besar Bahasa Indonesia, istilah Medis adalah termasuk atau berhubungan dengan bidang kedokteran. Kedokteran adalah ilmu dan seni yang 
mempelajari tentang penyakit dan cara-cara penyembuhannya. Jika ditarik garis lurus menggunakan tehnik silogisme maka dapat diartikan bahwa tindakan Invasif adalah suatu cara atau tindakan menyembuhkan penyakit. Hal ini menunjukkan bahwa tindakan invasif belum bisa dimaknai jika yang wajib melakukan adalah seorang dokter, bisa saja tenaga kesehatan lain yang memiliki kompetensi di bidang penyembuhan penyakit tersebut.

Hal tersebut diperkuat dengan pernyataan Tri Suyamti yang mengatakan bahwa sesuai dengan prinsip asuhan keperawatan maka perawat diperbolehkan melakukan tindakan invasif pada praktik keperawatan mandiri yang berfokus pada upaya penyelamatan jiwa, dan kegawatdaruratan. Di mana pasien dalam keadaan darurat sebelum dirujuk harus ada penanganan invasif sementara untuk pertolongan. Hal ini dilakukan agar jangan sampai terjadi kegawat daruratan yang fatal. Tindakan invasif boleh dilakukan sebagai pertolongan sebelum ada rujukan dan jika perawat praktik mandiri melakukan tindakan invasif berupa pemasangan infus dengan pasien menginap dirumahnya sendiri itu yang tidak diperbolehkan.

Berdasarkan uraian tersebut di atas dapat ditarik kesimpulan bahwa perawat yang memiliki kompetensi tindakan invasif memiliki kekuasaan dalam melakukan tindakan tersebut.

5) Ditinjau dari Aspek Administratif

Dari kuesioner yang dibagikan kepada perawat yang melakukan tindakan invasif pada praktik keperawatan mandiri diperoleh hasil: Tabel: 1.3

Kepemilikan dan Ketersedaan Berkas Adminsitrasi dalam Praktik Keperawatan

\begin{tabular}{lccc}
\hline \multicolumn{1}{c}{ Jenis } & $\begin{array}{c}\text { Ada } \\
(\%)\end{array}$ & $\begin{array}{c}\text { Tidak } \\
\text { Ada } \\
(\%)\end{array}$ \\
\hline $\begin{array}{l}\text { Kepemilikan STR dan } \\
\text { SIPP }\end{array}$ & $100 \%$ & \\
$\begin{array}{l}\text { Ketersediaan SOP } \\
\text { Ketersediaan Informed }\end{array}$ & $14 \%$ & $86 \%$ \\
\hline
\end{tabular}

\begin{abstract}
Consent dan Dokumen
Keperawatan setiap

pasien

Data di atas menunjukan bahwa

secara administrasi kelengkapan

pelayanan pada praktik keperawatan mandiri masih belum sempurna, ini dibuktikan dengan belum adanya SOP dan juga Informed Consent dan Dokumen Keperawatan pada praktik keperawatan mandiri. Ini sangatlah penting mengingat bahwa dengan adanya kelengkapan administrasi tersebut maka akan dapat melahirkan kewenangan atributif. Sebagaimana yang dituangkan dalam Pasal $58 \mathrm{UU}$ No. 36/2014 tentang Tenaga Kesehatan bahwa setiap tenaga kesehatan yang melakukan praktik wajib memberikan pelayanan sesuai dengan SOP, memperoleh persetujuan penerima pelayanan kesehatan, dan membuat dan menyimpan catatan dokumen tentang pemeriksaan, asuhan, dan tindakan yang dilakukan.

Berdasarkan uraian tersebut di atas dapat disimpulkan bahwa perawat yang melakukan tindakan invasif tidak memperoleh kewenangan atributif sepanjang belum melakukan SOP, Informed Consent dan Dokumen Keperawatan. Ini diperkuat dengan pernyataan Tri Suyamti yang mengatakan bahwa semua tenaga kesehatan wajib memiliki SOP, dan rekam medis dalam praktik mandirinya.
\end{abstract}

\section{b. Perlindungan Hukum Perawat dalam melakukan Tindakan Invasif pada Praktik Keperawatan Mandiri \\ Satjipto Raharjo mengemukakan} bahwa, perlindungan hukum itu adalah memberi pengayoman terhadap Hak Asasi Manusia (HAM) yang dirugikan orang lain dan perlindungan itu diberikan kepada masyarakat sehingga semua hakhak yang diberikan oleh hukum dapat mereka nikmati.

Menurut Soedikno Mertokusumo, perlindungan hukum adalah kewajiban dan jaminan hak manusia dalam rangka 
memenuhi kepentingan sendiri maupun di dalam hubungan masyarakat.

Menurut Sukendar dan Santoso, sarana perlindungan hukum dibagi menjadi 2 (dua) macam, yaitu:

1) Perlindungan hukum preventif adalah cara atau langkah yang dilakukan guna mencegah suatu kejadian yang dapat berakibat hukum.

2) Perlindungan hukum represif adalah cara atau langkah yang dilakukan apabila suatu kejadian yang berakibat hukum tersebut telah terjadi.

Perlindungan hukum kepada masyarakat selalu berkaitan erat dengan kekuasaan Lembaga Negara yang meliputi:

1) Legislatif yang bertugas membuat undang undang. Lembaga legislatif meliputi;MPR, DPR, dan DPD.

2) Eksekutif yang bertugas menerapkan dan melaksanakan undang-undang. Lembaga eksekutif meliputi presiden dan wakil presiden beserta menterimenteri yang membantunya.

3) Yudikatif yang bertugas mempertahankan pelaksanaan undang-undang. Lembaga yudikatif terdiri atas Mahkamah Konstitusi (MK), Mahkamah Agung (MA), dan Komisi Yudisial.

Perlindungan hukum bagi warga negara dari tindakan pemerintahan pada prinsipnya memiliki tujuan sebagai berikut:

1) Perlindungan hukum dalam rangka menjamin terpenuhinya hak-hak warga negara.

2) Perlindungan hukum dalam rangka mencegah terjadinya tindakan yang merugikan hak-hak warga negara.

3) Perlindungan hukum menyediakan akses bagi warga negara untuk menghentikan tindakan pelanggaran, mendapatkan ganti kerugian atau tindakan pemulihn atas pelanggaran haknya.

4) Perlindungan hukum dalam menjamin tersedianya ganti kerugian atautindakan pemulihan terhadap hak warga negara yang telah dirugikan.

Dari penjabaran teori di atas, diperoleh kejelasan tentang konsep perlindungan hukum bagi perawat yang melakukan tindakan invasif, yakni:

Tabel: 2.1

Upaya Perlindungan Hukum Bagi Perawat

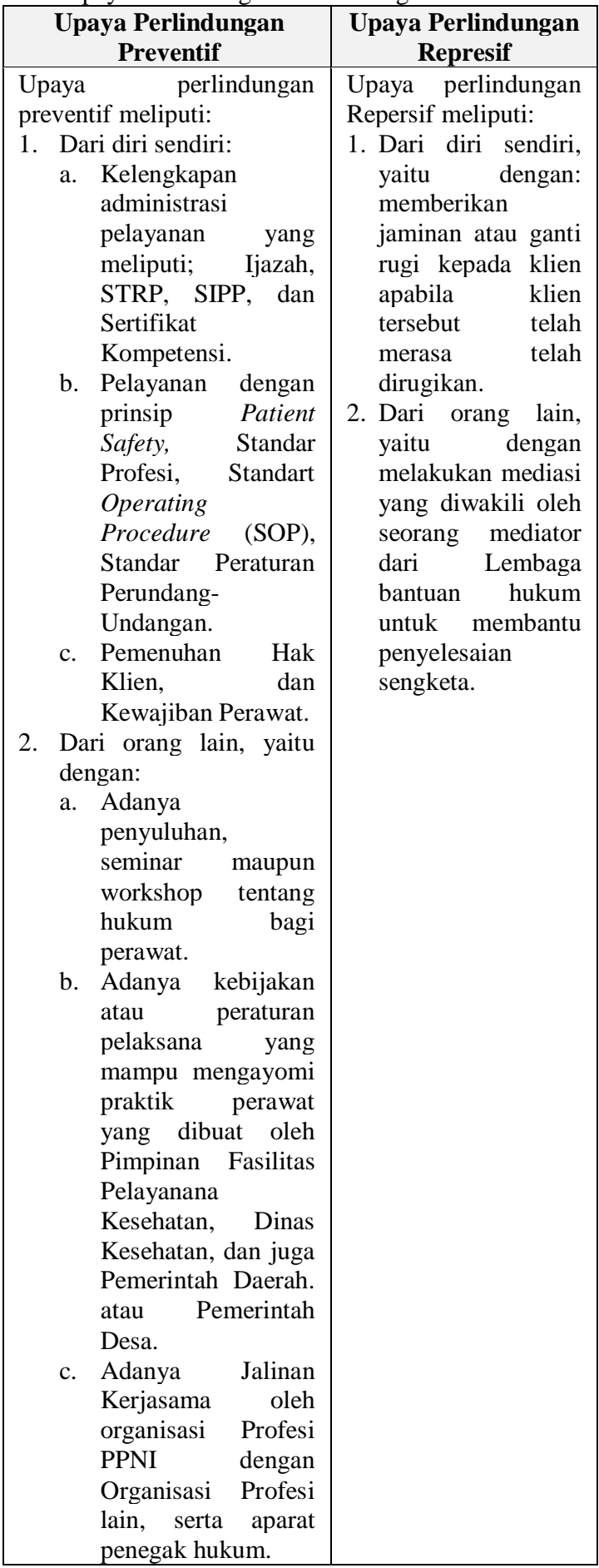


Tabel: 2.2

Jenis Perlindungan Hukum Bagi Perawat

\begin{tabular}{|c|c|c|}
\hline Ekonomi & Sosial & Politik \\
\hline $\begin{array}{l}\text { Pemenuhan } \\
\text { hak atas } \\
\text { imbalan dari } \\
\text { jasa yang telah } \\
\text { diberikan serta } \\
\text { pemakaian } \\
\text { segala fasilitas } \\
\text { yang diberikan } \\
\text { selama } \\
\text { menjalankan } \\
\text { profesinya. }\end{array}$ & $\begin{array}{l}\text { Pemenuhan } \\
\text { kesejahteraan } \\
\text { sosial yakni } \\
\text { terpenuhi } \\
\text { kebutuhan- } \\
\text { kebutuhan } \\
\text { dasarnya tenaga } \\
\text { Kesehatan } \\
\text { professional dari } \\
\text { negara dan } \\
\text { Lembaga- } \\
\text { lembaga di } \\
\text { bawahnya }\end{array}$ & $\begin{array}{l}\text { Implementasi } \\
\text { fungsi } \\
\text { Lembaga } \\
\text { 1. Legislatif, } \\
\text { 2. Eksekutif, } \\
\text { 3. Yudikatif. }\end{array}$ \\
\hline
\end{tabular}

Tabel: 2.3

Unsur Perlindungan Hukum Bagi Perawat

\begin{tabular}{|c|c|c|}
\hline $\begin{array}{c}\text { Unsur Tindakan } \\
\text { Melindungi }\end{array}$ & $\begin{array}{c}\text { Unsur Pihak- } \\
\text { Pihak yang } \\
\text { Melindungi }\end{array}$ & $\begin{array}{c}\text { Unsur } \\
\text { Cara-Cara } \\
\text { Melindungi }\end{array}$ \\
\hline $\begin{array}{l}\text { 1. Pembelaan dan } \\
\text { Bantuan } \\
\text { Hukum. } \\
\text { 2. Pembinaan dan } \\
\text { Pendampingan. } \\
\text { 3. Mediasi. }\end{array}$ & 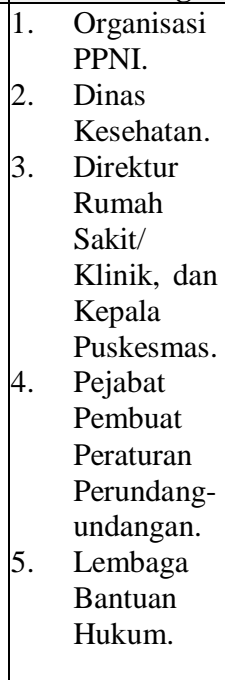 & $\begin{aligned} & \text { 1. } \text { Implemen } \\
& \text { tasi Hak } \\
& \text { dan } \\
& \text { Kewajiba } \\
& \mathrm{n} .\end{aligned}$ \\
\hline
\end{tabular}

Sebagai bentuk perlindungan hukum kepada perawat yang melakukan tindakan invasif pada praktik keperawatan mandiri, sebenarnya hal tersebut sudah terlihat dalam upaya hukum preventif yang dibuat oleh Lembaga Negara, yakni; UU No. 38/ 2014, dan Permenkes No. 26/2009.

Sebagaimana Pasal 36 huruf a UU No. 38/2014 tentang Keperawatan yang berbunyi:

"Perawat dalam melaksanakan Praktik Keperawatan berhak memperoleh pelindungan hukum sepanjang melaksanakan tugas sesuai dengan standar pelayanan, standar profesi, standar prosedur operasional, dan ketentuan Peraturan Perundangundangan".
Kemudian Pasal 58 ayat (2) UU No. 38/2014 tentang Keperawatan berbunyi: "Setiap orang yang tidak memiliki STR, tidak memiliki SIPP, tidak memasang papan nama praktik keperawatan mandiri, tidak memiliki kompetensi, akan dikenakan sanksi administratif berupa; teguran lisan, peringatan tertulis, denda administratif, dan pencabutan izin".

Hal serupa juga disampikan oleh Tri Suyamti yang mengatakan bahwa di Kota Surakarta tidak ada Perda yang mengatur secara khusus kewenangan dan perlindungan hukum bagi perawat, yang ada adalah peraturan dari pusat, yakni UU No.38/2014 dan Permenkes No. 26/2019, dan semua perawat telah mengetauhinya. Yang dilakukan Dinkes Kotas Surakarta selama ini dengan melakukan pembinaan dan pemantauan, selebihnya untuk sebuah kefatalan atau kegagalan diluar dugaan, Dinkes akan berupaya secara maksimal untuk melakukan pendampingan.

Di Bagian JDIH Pemkot Kota Surakarta, tidak ada perda yang mengatur tentang tindakan invasif pada perawat. Ini menandakan bahwa secara regulasi Pemkot Surakarta masih berpedoman pada peraturan yang ada yaitu UU No.38/2014 dan Permenkes No. 26/2019.

Yuli Muhammad Kartiko, mengatakan bahwa terkait perlindugan hukum bagi perawat yang menjalankan tindakan invasif, adalah dengan melakukan pembinaan dan pendampingan karena dikhawatirkan perawat yang bersangkutan akan melakukan pelayanan keperawatan melampaui dari batas kewajaranya.

Berdasarkan hasil analisis di atas, peneliti menyimpulkan bahwa perawat dalam transaksi terapeutik di bidang pelayanan keperawatan dilindungi oleh pemerintah pusat dan pemerintah daerah melalui peraturan perundang-undangan yang berlaku bagi pelaksana keperawatan. Pasien yang menerima tindakan invasif juga mendapatkan jaminan keselamatan sebagaimana tercantum dalam Pasal 58 ayat (1) UU 
No. 36 tahun 2009 tentang Kesehatan yang berbunyi:

"Setiap orang berhak menuntut ganti rugi terhadap seseorang, tenaga kesehatan, dan/atau penyelenggara kesehatan yang menimbulkan kerugian akibat kesalahan atau kelalaian dalam pelayanan kesehatan yang diterimanya".

\section{KESIMPULAN}

Dari uraian hasil dan pembahasan tersebut di atas, dapat ditarik kesimpulan:

a. Bahwa seorang perawat yang telah memiliki sertifikat ijazah profesi dan juga sertifikat kompetensi yang melakukan tindakan invasif sebagai bentuk keprofesionalitasan suatu profesi, dari aspek hukum kebiasaan diperbolehkan karena hal tersebut dilandaskan pada Pancasila Sila Ke-2 bahwa upaya yang dilakukan untuk menolong sesama itu merupakan perwujudan dari nilai kemanusiaan yang adil dan beradab. Kewenangan yang lahir atas tindakan invasif yang dilakukan oleh perawat merupakan keadaan overmacht sehingga menimbulkan kewenangan atributif yang merupakan implementasi dari hukum perikatan. Kewenangan dalam melakukan tindakan invasif diperbolehkan selama dilakukan sesuai dengan Standar Prosedur Operasional, Standar Profesi, Standar Kompetensi, dan Standar Peraturan Perundang-Undangan. Pelimpahan wewenang yang dituangkan pada Permenkes No. 26/2019 itu hanya berlaku di fasilitas pelayanan Kesehatan, seperti; rumah sakit, klinik, dan puskesmas. Selain itu, jika di daerah tempat perawat melakukan praktik keperawatan mandiri tidak ada tenaga medis, maka perawat memiliki kewenangan melakukan tindakan invasif tersebut karena hal ini ditujukan untuk program pembangunan kesehatan di masyarakat. Tindakan invasif yang dilakukan oleh perawat merupakan kewenangan yang hanya sebatas pelayanan insidental, dan tidak dilakukan secara terus menerus dalam janga waktu yang panjang. b. Bahwa perawat yang melakukan tindakan invasif pada praktik keperawatan mandiri secara preventif telah dilindungi oleh pemerintah pusat dan pemerintah daerah melalui pembinaan dan pengawasan oleh dinas kesehatan dan juga organisasi profesi PPNI meskipun belum ada Perda yang mengatur tentang tindakan invasif pada perawat tersebut. Yang terpenting adalah perawat yang bersangkutan melakukan tindakan invasif harus memperhatikan prinsip patient safety dan juga memiliki surat ijin praktik maupun kompetensi yang dikuasai.

\section{UCAPAN TERIMAKASIH}

Penulis mengucapkan banyak terimakasih terutama kepada Deputi Bidang Penguatan Riset dan Pengembangan, Kementerian Pendidikan, Kebudayaan, Riset dan Teknologi yang telah memberikan Hibah Penelitian Dosen Pemula. Semoga di kesempatan berikutnya penulis dapat diberikan kepercayaan kembali untuk melanjutkan penelitian ini.

Penulis juga mengucapkan terimakasih banyak kepada Universitas Duta Bangsa Surakarta yang telah membantu dan membimbing penulis untuk dapat mengakses dana Hibah Penelitian Dosen Pemula dari Kementerian Pendidikan, Kebudayaan, Riset dan Teknologi.

\section{REFERENSI}

Buku

Abdul Aziz, "Tinjauan Kriminologi Mengenai Malpraktik Medik yang Dilakukan oleh Perawat", Jurnal Ilmu Hukum Legal Opinion, Vol. 2, No. 2, 2014.

Ade Hikmat, 2014, Kreativitas, Kemampuan Membaca, dan Kemampuan Apresiasi Cerpen, Jakarta: Uhamka Press.

Aris Prio Agus Santoso, 2019, Hukum Administrasi Negara (Sebuah Pengantar bagi Mahasiswa), Yogyakarta: Nuta Media.

--------, dan Tatiana Siska Wardani, 2019, Etika Profesi Kefarmasian dan Hukum Kesehatan, Jakarta: Trans Info Media.

--------, 2020, Pengantar Ilmu Hukum, Yogyakarta: Pustaka Baru Press. 
2020, Hukum Kesehatan, Jakarta:

Trans Info Media

--------, dkk, 2021, Pengantar Filsafat

Hukum, Yogyakarta: Pustaka Baru Press.

Budiyanto, 2003, Dasar-Dasar Ilmu Tata Negara, Jakarta: Erlangga.

Departemen Pendidikan Nasional, 2001, Kamus Besar Bahasa Indonesia, Jakarta: Balai Pustaka.

Gerardus Gegen, dan Aris Prio Agus Santoso, "Analisis Yuridis Kewenangan Perawat dalam Pengobatan Bekam pada Praktik Keperawatan Mandiri”, Jurnal Ilmu Sosial dan Pendidikan, Vol 5, No. 3, 2021.

Hudi Purnama, 2017, Tesis: Diskresi Pelimpahan Wewenang Tindakan Medik dari Dokter kepada Perawat di Kotawaringin Timur, Surakarta: Magister Ilmu Hukum UMS.

Lexy J. Moleong, 2007, Metodologi Penelitian Kualitatif, Bandung: Alumni.

Marbun, 2012, Hukum Administrasi Negara Edisi 1, Yogyakarta: UII Press.

Mike Asmaria, 2016, Tesis: Persepsi Perawat Tentang Tanggung Jawab dalam Pelimpahan Kewenangan Dokter kepada Perawat di Ruang Rawat Inap Non Bedah Penyakit Dalam RSUP. DR. M. Djamil Padang, Padang: Universitas Andalas.

Noor M.Aziz, 2012, Hubungan Tenaga Medik,Rumah Sakit dan Pasien, Jakarta: Badan Pembinaan Hukum Nasional Kementrian Hukum dan Hak Asasi Manusia RI.

Sukendar, dan Aris Prio Agus Santoso, 2019, Tindak Pidana dalam Praktik Keperawatan Mandiri (Perlindungan Hukum bagi Perawat dan Pasien), Yogyakarta: Nuha Medika

Zaeni Asyhadie, 2017, Aspek-Aspek Hukum Kesehatan di Indonesia, Depok: Rajawali Pers.

\section{Jurnal}

Aris Prio Agus Santoso, dan Tatiana Siska Wardani, "Juridical Analysis of Nurse Authority in Granting of Red Label Drugs in The Mandiri Nursing
Practice", SOEPRA: Jurnal Hukum Kesehatan, Vol. 6, No. 1, 2019.

Arrie Budhiartie, "Pertanggungjawaban Hukum Perawat dalam Penyelenggaraan Pelayanan Kesehatan Di Rumah Sakit", Jurnal Penelitian Universitas Jambi Seri Humaniora, Vol. 11, No. 2, 2011.

Hario Mahar Mitendra, "Fenomena dalam Kekosongan Hukum", Jurnal Rechtsvinding, Vol. 1, 2018.

Gamal Abdul Nasir, "Kekosongan Hukum \& Percepatan Perkembangan Masyarakat", Jurnal Hukum Replik, Vol. 5 No. 2, 2017.

Mahfud, dan Patsun, "Mengenal Filsafat Antara Metode Praktik dan Pemikiran Socrates, Plato Dan Aristoteles", CENDEKIA: Jurnal Studi Keislaman, Vol. 5, No. 1, 2019.

\section{Peraturan}

RI, Undang-Undang Dasar 1945.

RI, Undang-Undang Nomor 36 Tahun 2009 tentang Kesehatan.

RI, Undang-Undang Nomor 36 Tahun 2014 tentang Tenaga Kesehatan.

RI, Undang-Undang Nomor 38 Tahun 2014 tentang Keperawatan.

RI, Peraturan Menteri Kesehatan Nomor 290/Menkes/Per/III/2008 tentang Persetujuan Tindakan Kedokteran.

RI, Peraturan Menteri Kesehatan Nomor 26 Tahun 2019 tentang Peraturan Pelaksanaan Undang-Undang Nomor 38 Tahun 2014 Tentang Keperawatan.

\section{Website}

BPPSDMK, Data Tenaga Kesehatan di Indonesia, diakses pada: http://bppsdmk.kemkes.go.id/info sdm k/info/ (Tanggal 11 September 2021).

JDIH Surakarta, Kumpulan Peraturan Daerah Kota Surakarta, diakses pada: https://jdih.surakarta.go.id/ (Tanggal 11 September 2021). 